Збірник наукових праць. Серія: Галузеве машинобудування, будівництво

Academic journal. Series: Industrial Machine Building, Civil Engineering

http://journals.pntu.edu.ua/znp

https://doi.org/10.26906/znp.2018.51.1298

UDC 624.131

\title{
Peculiarities of residential buildings deformation with connected block- sections collision as a result of uneven settlement on collapsible soils
}

\author{
Moskalina Ivan $^{1^{*}}$, Laschenko Yuriy ${ }^{2}$, Klimenko Andriy $^{3}$, Moskalina Viktor ${ }^{4}$ \\ ${ }^{1,2}$ Zaporizhzhia branch of State Enterprise «State Research Institute of Building Constructions» \\ https://orcid.org/0000-0002-2968-4851 \\ ${ }^{3}$ Zaporizhzhia branch of State Enterprise «State Research Institute of Building Constructions» \\ https://orcid.org/0000-0001-9124-4008 \\ ${ }^{4}$ Zaporizhzhia branch of State Enterprise «State Research Institute of Building Constructions» \\ https://orcid.org/0000-0002-7910-8297 \\ *Corresponding author: zvndibk@ukr.net
}

Instrumental inspections and studies experience and results of nine-storeyed residential buildings block-sections actual strained-deformed state under the conditions of their collision in territories of 25 to $35 \mathrm{~m}$ thick collapsible soils in Zaporizhzhia city and the subsidence value of $100 \mathrm{~cm}$ and more are summarized. It is shown that depending on the process of uneven settlement in the time value of deviation vectors is stabilized over time along with the stabilization of subsidence and deformation of block-section structures on the collision area. It has been established that uneven settlement growth processes stabilization, block-sections deviation from vertical and collision forces is achieved at equilibrium between subsidence values, collision forces of block-sections and resistance of wall sections.

Keywords: collapsible soils, block-sections collision, structures damage, protection, restoration

\section{Особливості деформування житлових будинків при зіткненні зблоко- ваних блок-секцій від нерівномірних осідань на просадочних грунтах}

\author{
Москаліна I.М. ${ }^{*}$, Лащенко Ю.М. ${ }^{2}$, Клименко А.O. ${ }^{3}$, Москаліна В.I. $^{4}$ \\ 1, 2, 3, 4 Запорізьке відділення ДП «Державний науково-дослідний інститут будівельних конструкцій» \\ *Адреса для листування: zvndibk@ukr.net
}

\begin{abstract}
3'ясовано, що досвід експлуатації житлових будинків на деформованих основах свідчить про актуальність таких результатів для їх урахування при експлуатації житлових будинків у складних інженерно-геологічних умовах. Наведено результати інструментальних обстежень фактичного напружено-деформованого стану конструкцій блоксекцій житлових будинків за умов їх зіткнення на просідаючих грунтах зі значними величинами просідань. При цьому відзначено, що на стадіях розроблення типових серій будинків і проектування конкретних будинків не враховувалося можливе зіткнення блок-секцій. Зрозуміло, що зусилля зіткнення блок-секцій є неврахованим впливом на конструкції будинку має ряд особливостей роботи конструкцій будинку в зоні зіткнення, одна 3 яких - навантаження ділянок стін зусиллями зіткнення із площини стіни. Узагальнено досвід експлуатації та результати інструментальних обстежень і досліджень фактичного напружено-деформованого стану блок-секцій дев'ятиповерхових житлових будинків за умов їх зіткнення на територіях 3 просадочними грунтами товщиною 25 - 35 м у м. Запоріжжя й величинами осідань і просідань 100 см та більше. Показано, що залежно від процесу розвитку нерівномірних осідань у часі величини векторів відхилення стабілізуються у часі паралельно зі стабілізацією осідань і деформуванням конструкцій блок-секції на ділянці ї зіткнення. Установлено, що стабілізація процесів зростання нерівномірних осідань відхилення блок-секцій від вертикалі й зусиль зіткнення досягається при рівновазі між величинами осідань, зусиллями зіткнення блок-секцій та опором ділянок стін.
\end{abstract}

Ключові слова: просадочний грунт, зіткнення блок-секцій, пошкодження конструкцій, захист, відновлення. 
Introduction. More than $80 \%$ of Ukraine territory is occupied by complex geotechnical conditions, including collapsing soils, undermined areas, karst phenomena, weak soils, etc.

A characteristic feature of these conditions is that during building and structure useful life they can get deformation of surface base and ground, negatively affect building operation [1].

Recent sources of research and publications analysis. In order to ensure the development of such territories, leading research and design institutions of Ukraine [5-9, 11] and abroad [10], integrated experimental research and design of various buildings and structures have been performed. Considerable volume is occupied by houses of various constructive decisions, which are used for mass development of the territory with such conditions.
Study of connected block-sections under the conditions of uneven settlement and block-sections collision in the last 20-30 years were not conducted. The results of instrumental observations of blocksections collision processes and deformations development in wall and ceiling structures are also not available. Experience in the operation of resitential houses on deformed bases indicates the relevance of such results for their consideration in residential buildings operation in complex engineering and geological conditions.

Selection of previously unsettled parts of the general problem.. When designing residential houses, the principles of block-sections blocking are often used. Figure 1 shows the schemes of blocking connected block-sections of residential buildings of mass development.

a)

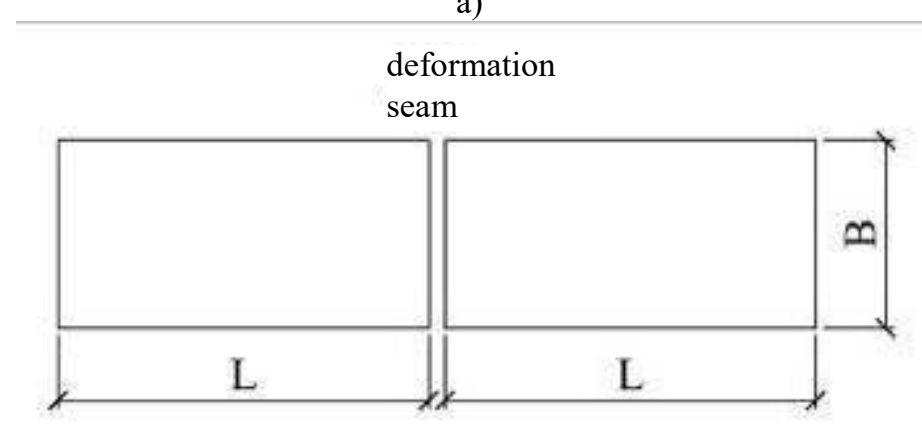

b)

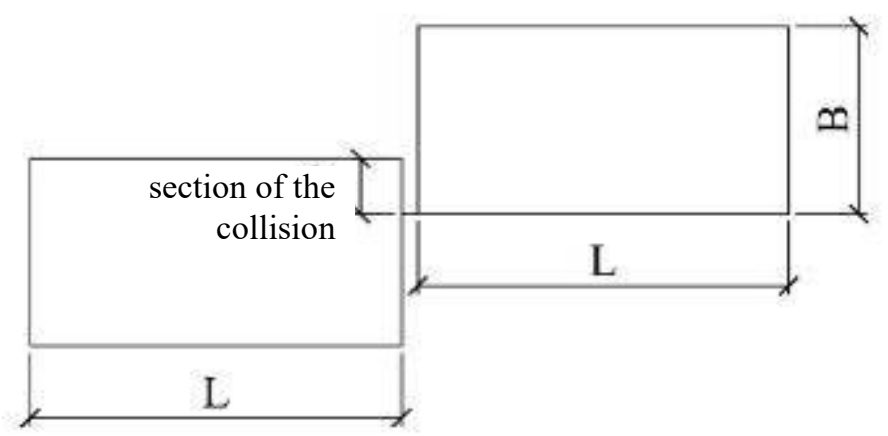

Figure 1 - Blocking circuit in terms of residential buildings block-sections:

a - without displacement in transverse direction;

$\mathrm{b}$ - with mutual displacement in transverse direction

From Figure 1 it can be seen that variants provide blocking of block-sections without mutual displacement in the transverse direction of blocksections and so displacements. Buildings operation experience shows that when uneven subsiding and tilting in block-sections collisions of the upper parts are formed. An important factor is the block section collision area magnitude. Figure 1 shows the blocking options for block-sections that are used on mass building of Ukrainian cities. The practice of designing residential buildings shows that the areas of block- sections collision vary from $100 \%$ of block-section width (B) to $30 \%$ of the width. It is obvious that at areas of block-section collision $50-30 \%$ of the block section width with deformation and damage of blocksections structures in the zone of their collisions is more intensive than when collision of block-sections is across the width.

It should be noted that at the stages of buildings typical series and specific houses designing development, the possible collision of block-sections has not been considered. The collision force of block- 
sections is not considered by the influence on the building design, it has a number of building construction features in the collision zone, one of which is the loading of wall sections by collision forces from wall plane.

Setting objectives. The article summarizes the experience of exploitation and the results of instrumental sinspection and studies of actual straineddeformed state of block-sections of nine-story residential houses in the conditions of their collision in areas with collapsible soils of Zaporizhzhia with a depth of $25-35$ meters and the values of sedimentation and sinking of $100 \mathrm{~cm}$ and more [2].
The main material and the results. Figures 2, 3 give a general view of a residential building and block-sections collision zone in a deformation joint with a $30 \%$ area of collision from the width of block section.

At the same time, the gap between the blocksections along the top of a deformation joint on this house was $250 \mathrm{~mm}$ under the project.

Figure 4 shows the indicative vectors of blocksections deviation from the vertical at the level of their top when they collide.

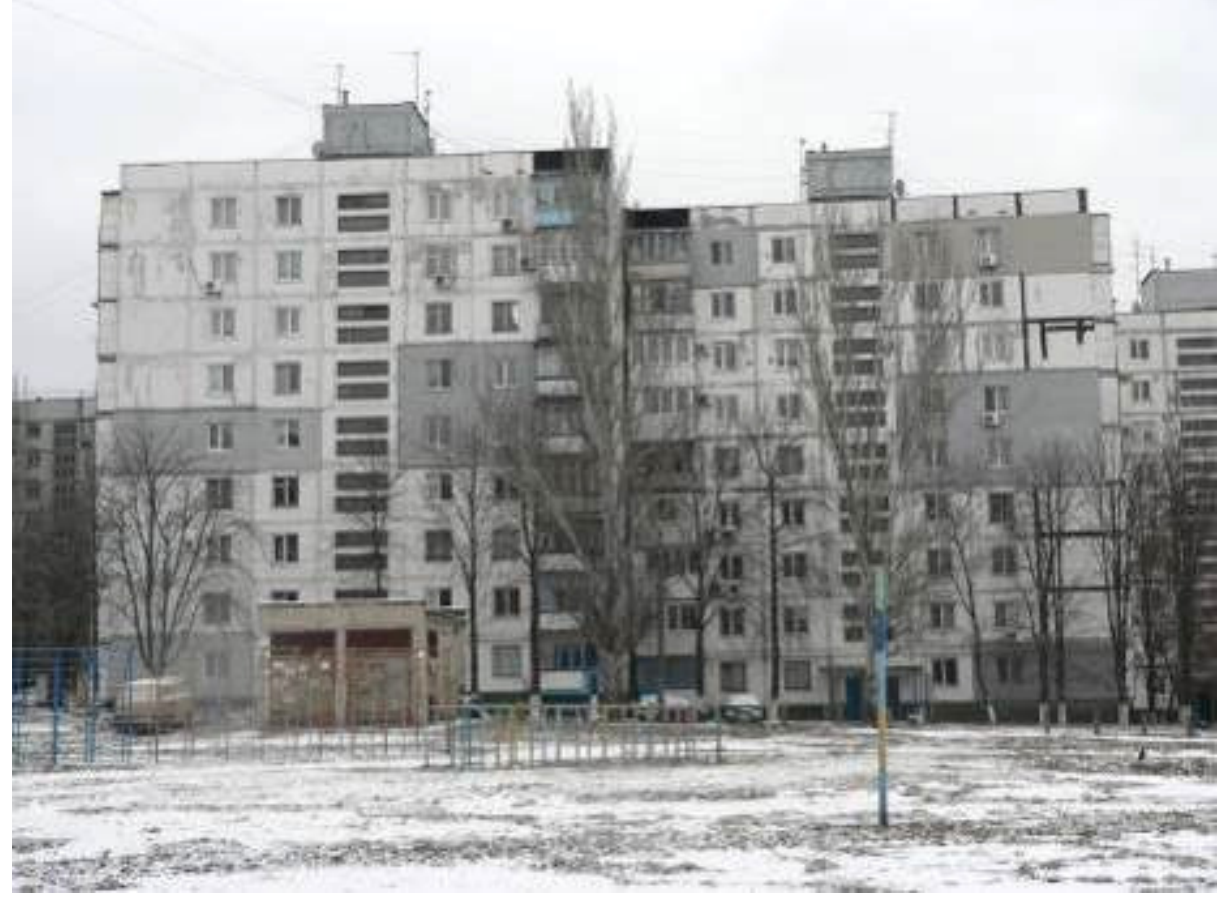

Figure 2 - General view of a residential building with collision of block-sections
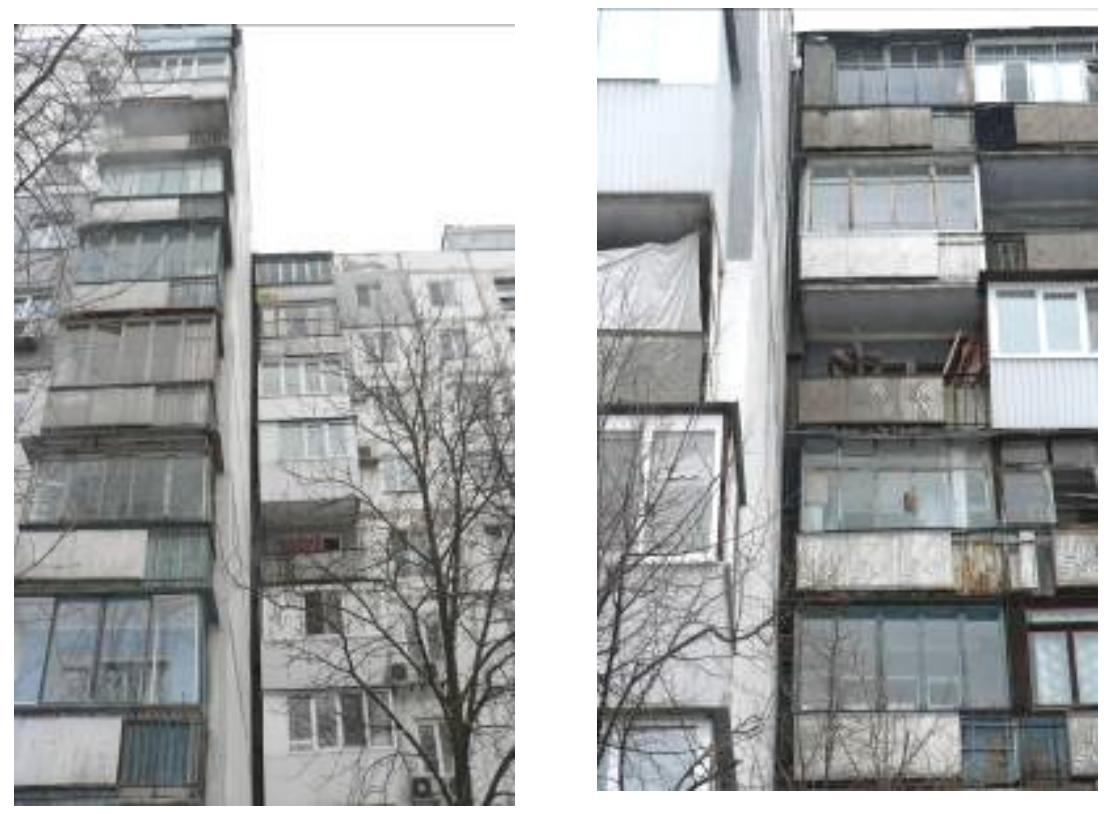

Figure 3 - The areas of house block-sections collision in a deformation joint 


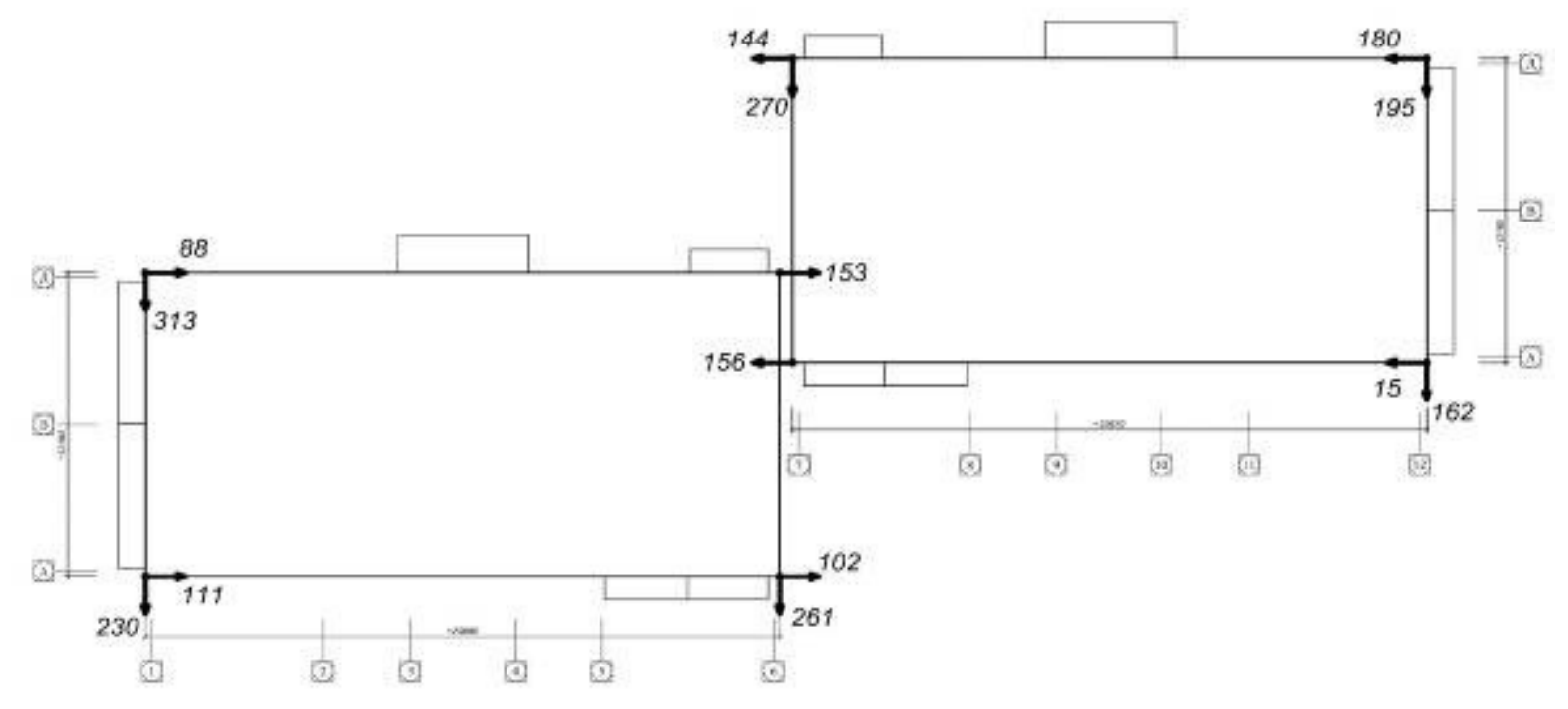

Figure 4 - Indicative vectors of deviation from vertical at the level of block-sections top when they collide

The unevenness of settlement on each block-section at the moment of measuring the block-sections deviation values was $225-250 \mathrm{~mm}$. Depending on the values of uneven settlement and their distribution, in terms of each block-section, block-sections deviation magnitude is different. Depending on uneven settlement process course increasing in time, the values of the deviations vector stabilize in time in parallel with deposition stabilization and blocksections structures deformation in the area of their collision. Processes stabilization of block-sections deviation uneven settlement increasing from the vertical and the collision forces is achieved with the equilibrium between the values of uneven settlement, the efforts of block-sections collision and walls resistance. The values of structural elements deformation and damage are conditioned by the magnitude of block-sections collision force. With the values of block-sections deviations vectors (tilt) shown in Figure 4, deformations and damage of the panels and their joints in the area of block-sections collision are recorded. Along a deformation joint, complete «closure» of the gap between block-sections outer walls planes at the level of the ninth and eighth floors is formed. Panels joints opening is up to $6 \mathrm{~mm}$. The cracking in the wall panels reaches $6-8 \mathrm{~mm}$. The zones of panels damage by grid of cracks are also fixed with the fragmentation of panel concrete by the efforts of plane pressure with the areas up to $1-3 \mathrm{~m}^{2}$. Slabs of the overlap formracks with opening up to $0,3-0,5 \mathrm{~mm}$. According to the criteria [2], structures technical state in the zone of block-sections collision in general has reached the $\langle 3 »$ category - unsuitable for normal exploitation. According to the criteria [2], structures technical state in block-sections collision zone in general has reached the $\langle 3 \mathrm{~d} »$ category unsuitable for normal exploitation.
The study of a residential building connected blocksections with three block-sections structures deformations with values of the collision areas on the deformation joint of $70 \%$ of the block-sections width has been carried out.

Maximum uneven settlement for each block-section ranged from $294-350 \mathrm{~mm}$ to $488-507 \mathrm{~mm}$. In this case, the maximum vectors of the top block-sections deviation from the vertical were $330-350 \mathrm{~mm}$. It has been established that in zones with blocksections collision of panels deformation and floor slabs, their joints are more intense on the upper floors (the ninth and the eighth). The joints in the panels reached $1.5-2.5 \mathrm{~mm}$. In separate panels, cracks opening was up to $4 \mathrm{~mm}$. Cracks detection in the panels was $0.4-1.5 \mathrm{~mm}$. In overlappings slabs, the main crack opening did not exceed $0.3-0.5 \mathrm{~mm}$.

In staircase cover, slab joints opening reaches 3-4 $\mathrm{mm}$ with areas of damage to the joints and zones of long soaking by atmospheric precipitation.

The values of deformation at the level of the ninth floor overlay were:

- joints of sites with wall panels, elevator shaft opening - mainly up to $1 \mathrm{~mm}$;

- joints disclosure of intermediate platforms, staircase marches in refinement knots - up to $1 \mathrm{~mm}$.

At the levels of the eighth, seventh floors, the values of similar deformations are $1-3 \mathrm{~mm}$. At the levels of the sixth, fifth floors they are in the range of $0.5-1 \mathrm{~mm}$. From the fourth to the first floor, the opening of slabs, stairs and marches joints does not generally exceed $0.5 \mathrm{~mm}$. All structures and joints of deformation magnitude exceeded the limit, regulated by normative documents, have the « 3 » category of technical condition, and require the performance of repair and restoration work. 
The received values of block-sections structures deformations comparison shows that with the magnitude of the collision area up to $70-100 \%$ increase in the unevenness of settlement and deviation from the vertical almost twice - structures deformation of block-sections in the collision zones have smaller values than with the magnitude of the collision zone $30 \%$

It should be noted that the given results are obtained with the size of the deformation joint on the project between block-sections of $250 \mathrm{~mm}$.

It is important that the inhabitants of apartments located in the zones of block-sections collision in the process of forming collision and development of deformations and damage in the collision zone repeatedly performed «decorative» repairs of damage parts, but with further uneven settlement of blocksection - areas of deformation and damage appeared and increased.

According to the requirements [2], in the technical condition of structures « 3 » and « 4 » category, it is necessary to restore, reinforce or replace damaged structures in order to ensure inhabitants safety in premises with such structures.

In such situations, the necessary step is to repair block-sections using the alignment technologies and bringing block-sections with a till to avertical position.

At State Research Institute of Building Constructions the technologies of leveling houses have been designed the most:

-method of using the hydraulic jacks system;

-method of exterminating the soil under blocksections foundations.

Each method has its own peculiarities and conditions of rational use. After eliminating the tills, repair and renovation works on deformed and damaged house structures are carried out.

Considering the possibility of block-sections collisions repeated formation on subsurface soils with significant amounts of settlement, the most radical approach is, after blocks removing from block-section (alignment), to fix foundation base to eliminate the possible formation of uneven settlement in future according to the State Standard-NSC.1.1-44: 2016 [3].

Conclusions. Deformation and damage of residential buildings under the conditions of block-sections collision are specific influences on the design of building block section upper part. Such influences have been not considered at the stage of block-section designs and residential buildings design under specific building conditions development. On territories formed by collapsible soils with a thickness of 20-30 $\mathrm{m}$ and the values of subsidence and shrinkage of $100 \mathrm{~cm}$ or more when block-sections collision is formed in deformated and damaged structure technical condition category« $3 »$ and «4», which excludes the normal further operation of such block-sections and significantly increases operating costs. The number of block-sections multiple collisions where tilts were previously eliminated, increases in time. Necessary measures are speedy repair and restoration work with the main stages: block-sections tilts (leveling) elimination; repair and restoration works performance.

On soils with significant values of subsidence it is rational, after removing the blocks of the blocksection (alignment), to fix foundation base to eliminate the possible formation of uneven settlement in time. Necessary factor is technologies practical implementation and development for restoring bearing capacity, bearing structural elements with significant damage strength in the areas of block-sections collision under the conditions of access from internal premises. The obtained results enable to carry out built-up areas analyzes of cities with connected sections of residential buildings and to develop the necessary preventive measures for collisions reduction or their complete exclusion. Biased analysis of builtup areas in Ukrainian cities with the identification of potentially dangerous block-sections in the conditions of block-sections collisions and tilts manifestation is important and expedient. Such biased analyzes and measures provide minimization of risks and consequences for residential buildings operation, as well as significant reduction in operating costs.

\section{References}

1. ДБН В.1.1-45:2017. (2017). Будівлі і споруди в складних інженерно-геологічних умовах. Загальні положення. Київ: Мінрегіонбуд України, Укрархбудінформ.

2. ДСТУ-НБВ.1.2-18:2016. (2017). Настанова щоодо обстеження будівель і споруд для визначення та оцінки їх технічного стану. Київ:

ДП УкрНДНЦ.

3. ДСТУ-НБВ.1.1-44:2016. (2017). Настанова щодо проектування будівель і споруд на просідаючих трунтах. Київ: ДП УкрНДНЦ.

4. ДСТУ БВ.3.1-2:2016. (2017). Ремонт і niдсилення несучих і огороджувальних будівельних конструкиій та основ будівель $і$ споруд. Київ: ДП УкрНДНЦ.

5. Клепиков, С.Н. (1996). Расчет сооружений на деформируемом основании. Київ: НИИСК.

6. Петраков, А.А. (1997). Исследование предельных состояний сооружений на деформируемом основании. Современные проблемы строительства: науч.-техн. сборник, 3, 22-28.

7. Москалина, И.Н., Трегуб, А.С. \& Григорьев, Г.М. (1997). Экспериментальные исследования крупнопанельных зданий новых конструктивных решений для их строительства на подрабатываемых территориях Донбасса Современные проблемы строительства: науч.-техн. сборник, 3, 28-32.

8. Григорьев, Г.М., Трегуб, А.С. \& Москалина, И.Н. (1997). Экспериментальные исследования крупнопанельных зданий и закономерности трещинообразования в их несущих элементах под влиянием просадок. Будівельні конструкиії: зб. наук. працьь, 24, 142-148. 
9. Клепиков, С.Н., Трегуб, А.С. \& Москалина, И.Н. (1980). Испытание зданий на прочность и устойчивость. Основания, фундаменты и механика грунтов, 4, 7-8.

10. Smirakova, M., Mateckova, P. \& Buchta, V. (2016). Deformation of Foundation Structure and their Experimental Testing. International Journal of Theoretical and Applied Mechanics, 1, 303-308.

11. Kryvosheiev, P., Farenyuk, G., Tytarenko, V., Boyko, I., Kornienko, M., Zotsenko, M., Vynnykov, Yu., Siedin, V., Shokarev, V., Krysan, V. (2017). Innovative projects in difficult soil conditions using artificial foundation and base, arranged without soil excavation. Proc. of the $19^{\text {th }}$ International Conf. on Soil Mechanics and Geotechnical Engineering (Sep. 17 - 22, 2017 / COEX, Seoul, Korea), Seoul. 